PNL-7153

UC-510

$3=$

\title{
Hanford Protective Barriers \\ Program: Status of Asphalt \\ Barrier Studies - FY 1989
}

H. D. Freeman

G. W. Gee

November 1989

Prepared for the U.S. Department of Energy under Contract DE-AC06-76RLO 1830

Pacific Northwest Laboratory

Operated for the U.S. Department of Energy by Battelle Memorial Institute 


\title{
DISCLAIMER
}

This program was prepared as an account of work sponsored by an agency of the United States Government. Neither the United States Government nor any agency thereof, nor Battelle Memorial Institute, nor any or their employees, makes any warranty, expressed or implied, or assumes any legal liability or responsibility for the accuracy, completeness, or usefulness of any information, apparatus, product, or process disclosed, or represents that its use would not infringe privately owned rights. Reference herein to any specific commercial product, process, or service by trade name, trademark, manufacturer, or otherwise, does not necessarily constitute or imply its endorsement, recommendation, or favoring by the United States Government of any agency thereof, or Battelle Memorial Institute. The views and opinions of authors expressed herein do not necessarily state or reflect those of the United States Government or any agency thereof.

\author{
PACIFIC NORTHWEST LABORATORY \\ operated by \\ BATTELLE MEMORIAL INSTITUTE \\ for the \\ UNITED STATES DEPARTMENT OF ENERGY \\ under Contract DE-AC06-76RLO 1830
}

Printed in the United States of America

Availabie to DOE and DOE contractors from the

Office of Scientific and Technical Information, P.O. Box 62, Oak Ridge, TN 37831;

prices available from (615) 576-8401. FTS 626-8401.

Available to the public from the National Technical Iniormation Service,

U.S. Department of Commerce, 5285 Port Royal Rd., Springfield, VA 22161.

NTIS Price Codes, Microfiche A01

Printed Copy

\begin{tabular}{|c|c|}
\hline Pages & $\begin{array}{l}\text { Price } \\
\text { Codes }\end{array}$ \\
\hline $001-025$ & $\mathrm{~A} 02$ \\
\hline $026-050$ & $\mathrm{~A} 03$ \\
\hline $05+-075$ & $\mathrm{~A} 04$ \\
\hline $076-100$ & A0s \\
\hline $101-125$ & A06 \\
\hline $126-150$ & $\mathrm{~A} 07$ \\
\hline $151-175$ & $\mathrm{~A} 08$ \\
\hline $176-200$ & $\mathrm{~A} 09$ \\
\hline $201-225$ & A10 \\
\hline $226-250$ & A 11 \\
\hline $251-275$ & $\mathrm{~A} 12$ \\
\hline $276-300$ & A.13 \\
\hline
\end{tabular}


HANFORD PROTECTIVE BARRIERS PROGRAM:

STATUS OF ASPHALT BARRIER STUDIES - FY 1989

H. D. Freeman

G. W. Gee

November 1989

Prepared for the U.S. Department of Energy under Contract DE-ACO6-76RLO 1830 


\section{SUMMARY}

The Hanford Protective Barrier Program is evaluating alternate barriers to provide a means of meeting stringent water infiltration requirements. One type of alternate barrier being considered is an asphalt-based layer, 1.3 to $15 \mathrm{~cm}$ thick. Evaluations of these barriers were initiated in FY 1988, and, based on laboratory studies, two asphalt formulations were selected for further testing in smal1-tube 1ysimeters: a hot rubberized asphalt and an admixture of cationic asphalt emulsion and concrete sand containing 24 wt\% residual asphalt. Eight lysimeters containing asphalt seals were installed as part of the Small Tube Lysimeter Test Facility on the Hanford Site. Two control lysimeters containing Hanford sand with a surface gravel treatment were also instalied for comparison.

Fiscal Year 1989 studies focused on monitoring the 1ysimeter tests and repeating a number of the admixture formulation tests using a slightly modified test procedure. Drainage measurements and tracer tests indicate that the asphalt barriers have not leaked during the first 12 months of lysimeter monitoring. The control lysimeters, on the other hand, showed significant breakthrough after 9 months of exposure. An average of 31\% of the precipitation measured at the Hanford Meteorological Station was stored in all the lysimeters after 12 months exposure. In addition, the gravel-covered controls drained $4.4 \mathrm{~cm}$ or an additional $27 \%$ of the total precipitation. The average storage for all lysimeters is higher than expected for a bare soil surface, but less than expected for a thick surface grave1 cover. The discrepancy may be attributable to the air gap around each of the lysimeters, which allows the soil in the lysimeters to warm to higher temperatures than found in undisturbed soit. These higher temperatures would result in higher evaporation rates and, hence, lower water storage. This potential bias will be addressed in FY 1990 by installing insulation collars around each lysimeter. 


\section{CONTENTS}

SUMMARY ............................ . . i ...

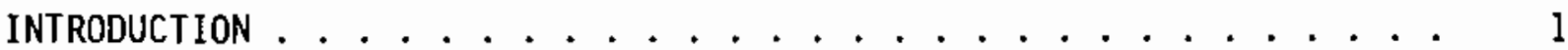

LYSIMETER STUDIES . . . . . . . . . . . . . . . . . 3

METEOROLOGICAL DATA . . . . . . . . . . . . . . . 3

Precipitation Data . . . . . . . . . . . . . 5

Temperature Data . . . . . . . . . . . . . . 6

LYSIMETER WATER BALANCE . . . . . . . . . . . . . . . 6

LYSIMETER DRAINAGE DATA . . . . . . . . . . . . . . 12

Drajnage Volume . . . . . . . . . . . . . . 12

Drainage Tracer Studies . . . . . . . . . . . . 13

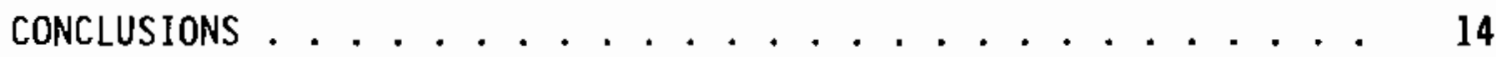

ASPHALT ADMIX FORMULATION STUDIES . . . . . . . . . . . . . . . . 15

REFERENCES ........................... . . . . 17

APPENDIX - LYSIMETER MONITORING DATA . . . . . . . . . . . . . A.1 


\section{FIGURES}

1 Lysimeter Treatment Layout at the Small Tube Lysimeter Test

Facility ................... 3

2 Cross-Sectional View of Lysimeter Layers . . . . . . . . . 4

3 Comparison of Actual and Average Monthly Rainfall at the Hanford Meteorological Station ............ 5

4 Precipitation Measured During Lysimeter Monitoring Intervals . . 6

5 Temperature Data Measured at the Hanford Meteorological

Station .................. . . 7

6 Water Storage in the Rubberized Asphalt Lysimeters . . . . . . 8

7 Water Storage in the Asphait Admix Lysimeters ......... 9

8 Water Storage in the Control Lysimeters........... 9

9 Evaporation from the Rubberized Asphalt Lysimeters . . . . . . 10

10 Evaporation from the Asphalt Admix Lysimeters . . . . . . . 11

11 Evaporation from the Control Lysimeters . . . . . . . . . 11

12 Cumulative Drainage from the Alternate Barrier Lysimeters . . . . 12

13 Conductivity of Drain Water Collected Before and After Injection of Saturated $\mathrm{NaCl}$ Solution ............ 14 


\section{INTRODUCTION}

The Hanford Protective Barrier (HPB) Program, sponsored by the U.S. Department of Energy and jointly managed by Pacific Northwest Laboratory (PNL) (a) and Westinghouse Hanford Company (WHC), is considering asphalt, clay, and chemical grout as additions to earthen barriers for restricting the infiltration of water into waste sites on the Hanford Site (Adams and Wing 1986). Pacific Northwest Laboratory is evaluating asphalt materials, while WHC is evaluating clay and chemical grout.

This report covers the results of asphalt barrier studies conducted by PNL in FY 1989. These studies are a continuation of work initiated in FY 1988 (Freeman and Gee 1989). The aspha7t barrier studies for the HPB Program are divided into three categories: 1) laboratory studies, 2) lysimeter studies, and 3) field demonstration. Work for FY 1989 focused on the lysimeter studies but also included a number of laboratory tests on asphalt emulsion/concrete sand formulations.

The lysimeter studies are being conducted to evaluate the performance of asphalt barrier formulations under natural environmental conditions. The effects of infiltration and root penetration on seal integrity are being assessed to determine the feasibility of using these materials as part of the Hanford Protective Barrier. The lysimeters, which are $30 \mathrm{~cm}$ in diameter, were installed in July 1988 (Freeman and Gee 1989) near the Hanford Meteorological Station (HMS) as part of the 100-7ysimeter Sma11 Tube Lysimeter Test Facility (STLTF) (Waugh and Link 1987).

(a) Operated for the U.S. Department of Energy by Battelle Memorial Institute under Contract DE-AC06-76RLO 1830. 



\section{LYSIMETER STUDIES}

This section contains the meteorological, water balance, and drainage data collected during the FY 1989 lysimeter studies. The layout of the lysimeters with associated treatments is shown in Figure 1. Figure 2 shows a cross-sectional view of the two asphalt layer treatments (a $15-\mathrm{cm}$-thick compacted asphalt emulsion layer and a 1.3-cm-thick rubberized asphalt layer) plus the control lysimeter (no asphalt layer). All 10 lysimeters have a 15-cm-thick gravel cover. The gravel material is washed, sorted river rock ranging from 2 to $2.5 \mathrm{~cm}$ in diameter.

\section{METEOROLOGICAL DATA}

Meteorological data used to analyze the performance of the lysimeters are obtained from the HMS, which is located near the STLTF. Monthly summary sheets show daily averages for variables such as minimum, maximum, and average temperatures; wind speed and direction; and precipitation. A summary
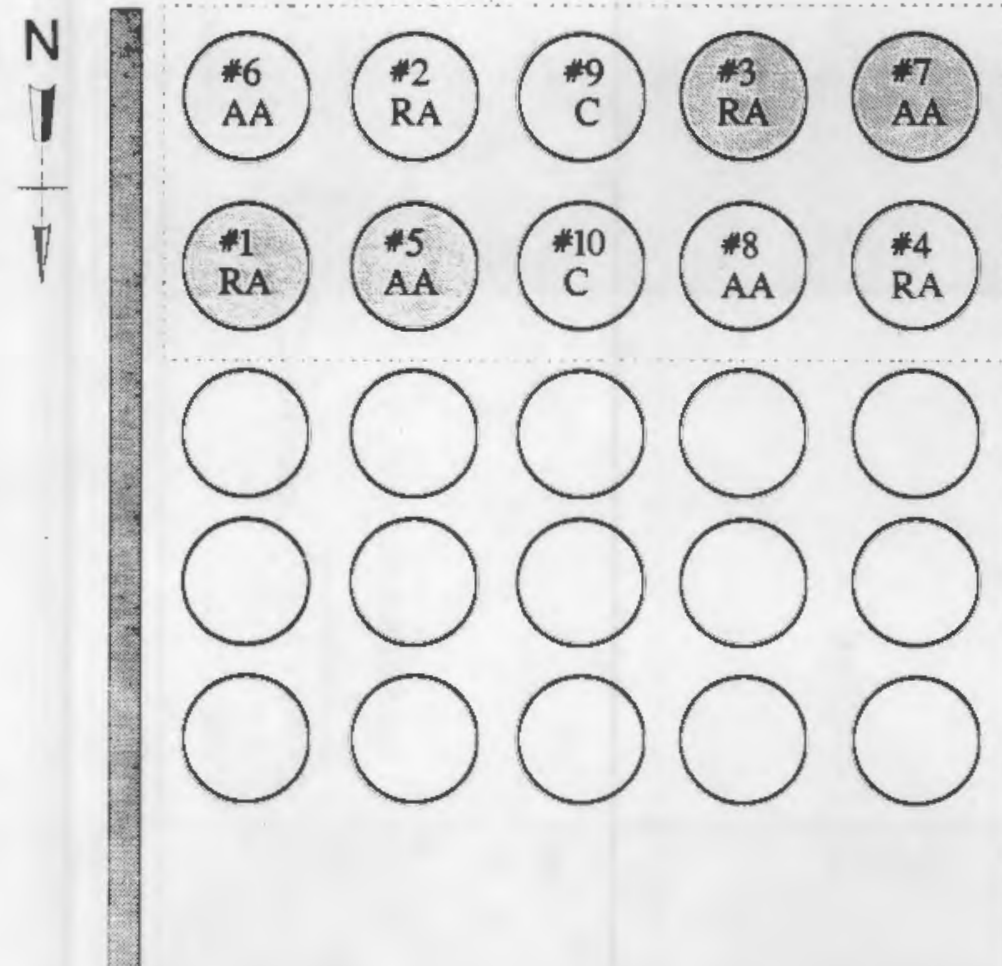

Clay/Grout Lysimeters
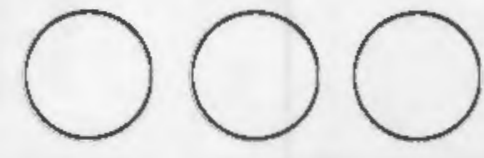

Asphalt Lysimeters

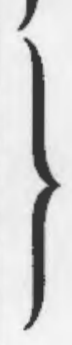

RA $=$ Rubberized Asphalt

$A A=$ Asphalt Admix

$\mathrm{C}=$ Control

Tegetation

FIGURE 1. Lysimeter Treatment Layout at the Smal1 Tube Lysimeter Test Facility 
Asphalt Admix

$\rightarrow$
Rubberized Asphalt

$15 \mathrm{~cm}$ Gravel

$1.0 \mathrm{~m}$ Sand

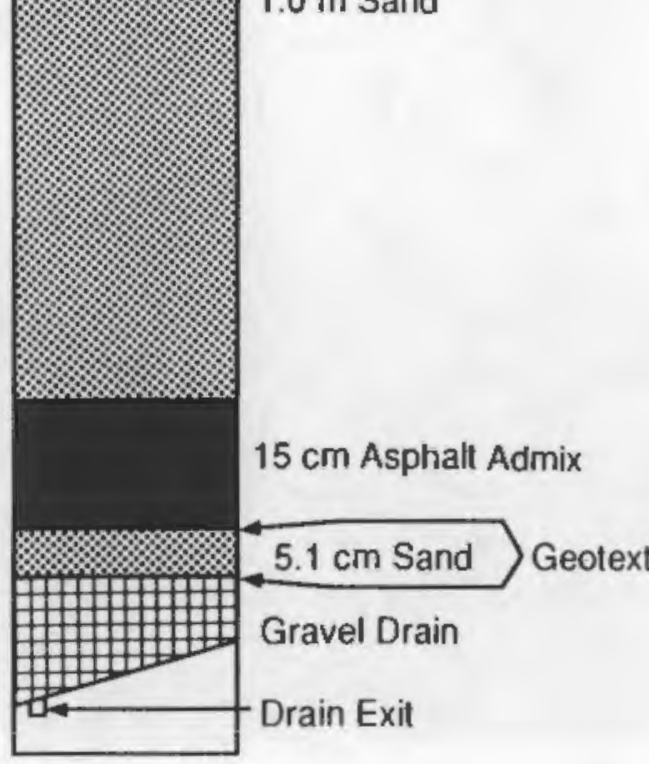

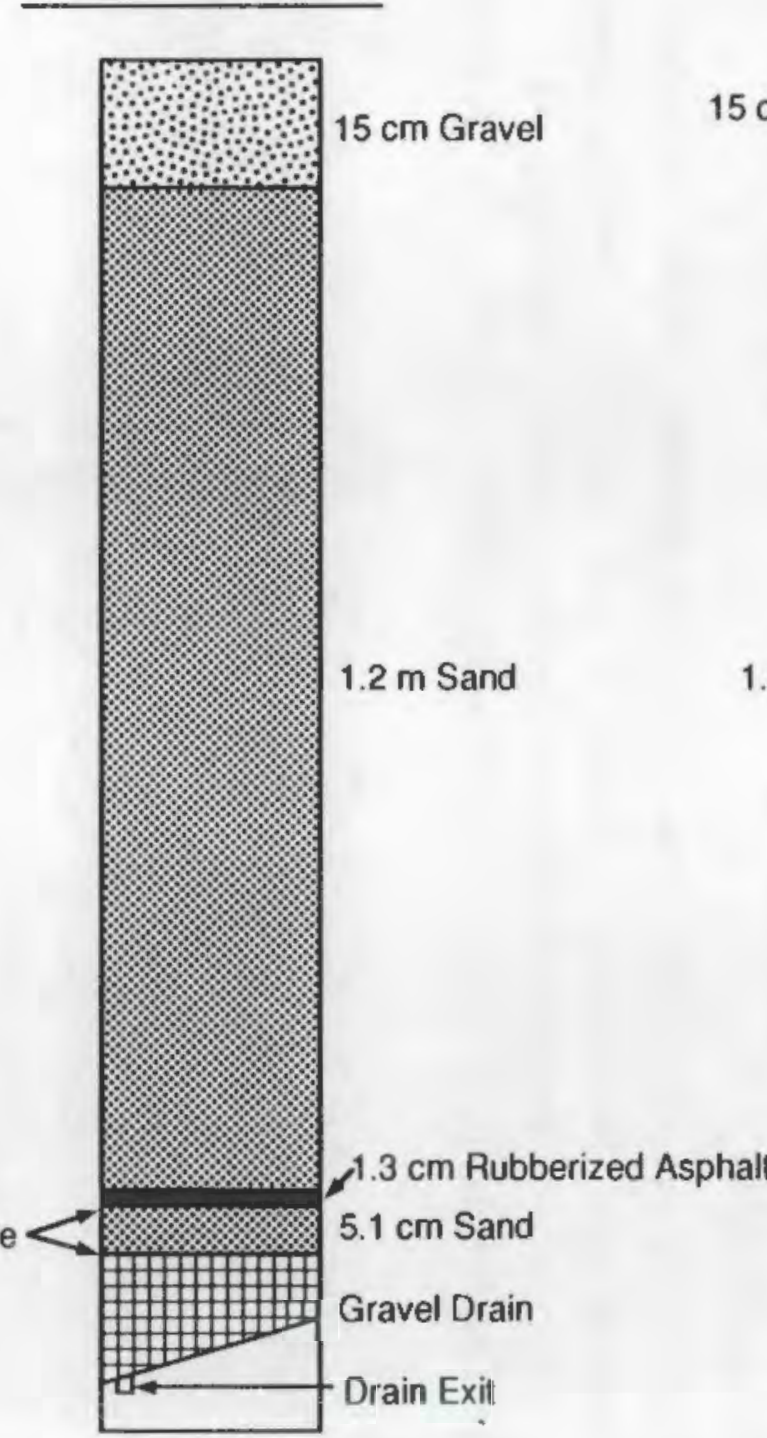

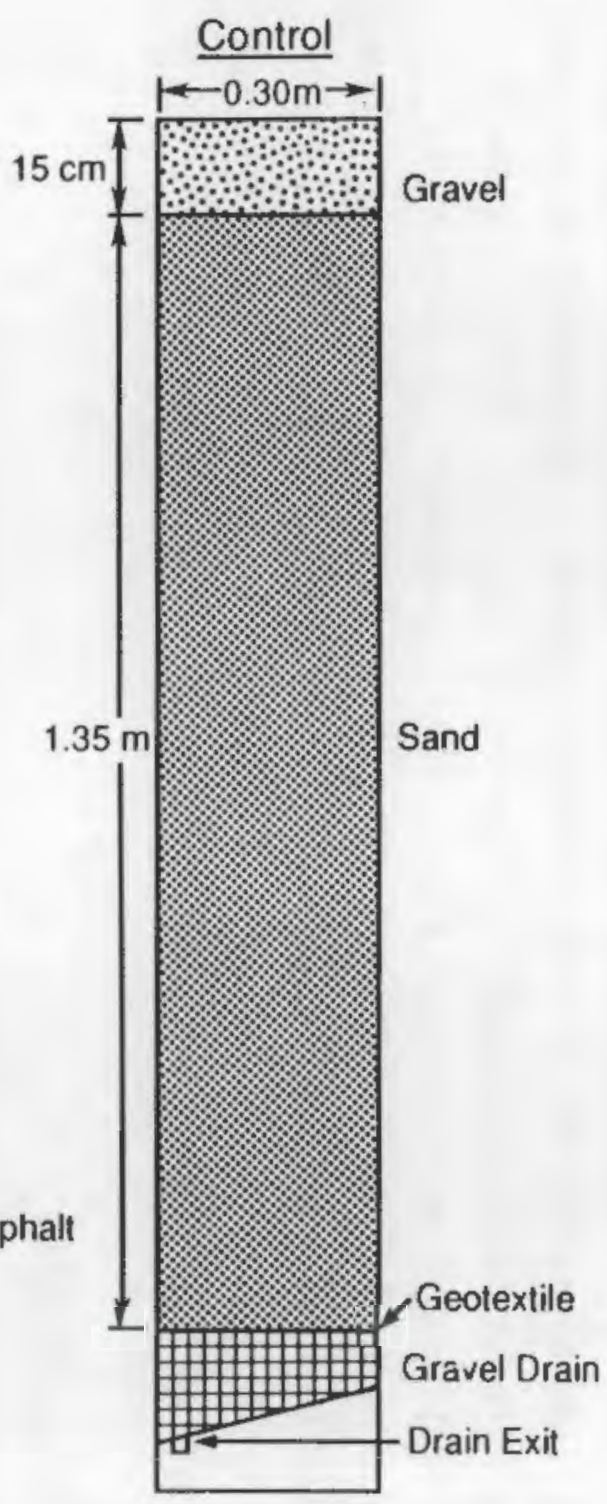

FIGURE 2. Cross-Sectional View of Lysimeter Layers 
of the temperature and precipitation data for August 1988 through July 1989 is presented here to provide baseline data for interpreting the lysimeter storage, evaporation, and drainage data presented in later sections.

\section{Precipitation Data}

The monthly actual and average precipitation data for the monitoring period are compared in Figure 3. This figure shows that during the summer and fall of 1988 lower than average precipitation was recorded, while during the winter of 1988-1989 higher than normal precipitation was observed. The cumulative rainfall of $16.59 \mathrm{~cm}$ (from August 1988 through July 1989) is only slightly higher than the average annual precipitation recorded at Hanford between 1912 and 1980 . The precipitation measured between monitoring periods is shown in Figure 4. Data from Figure 4 were used to estimate the relative storage and evaporation.

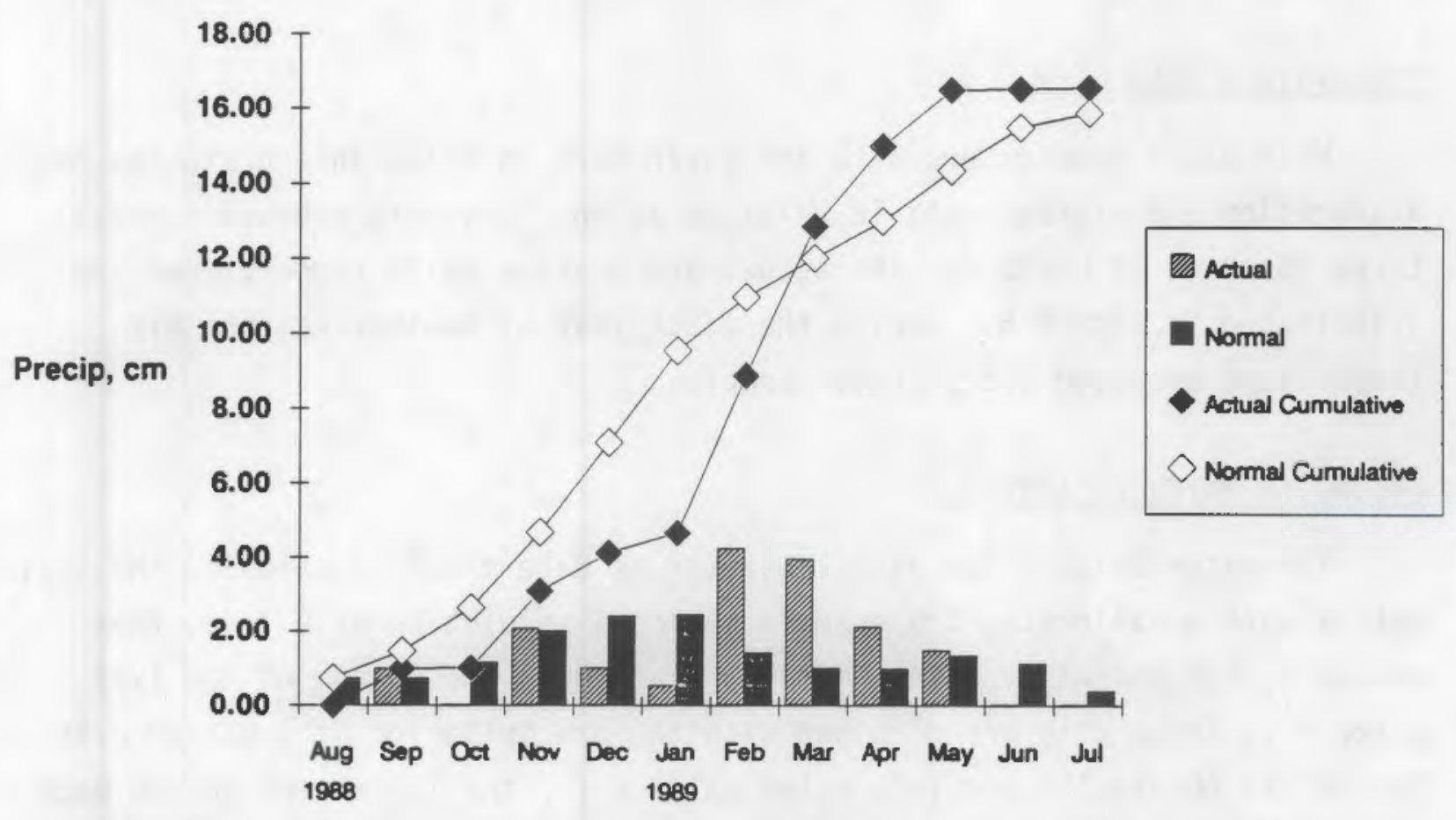

FIGURE 3. Comparison of Actual and Average Monthly Rainfall at the Hanford Meteorological Station. 


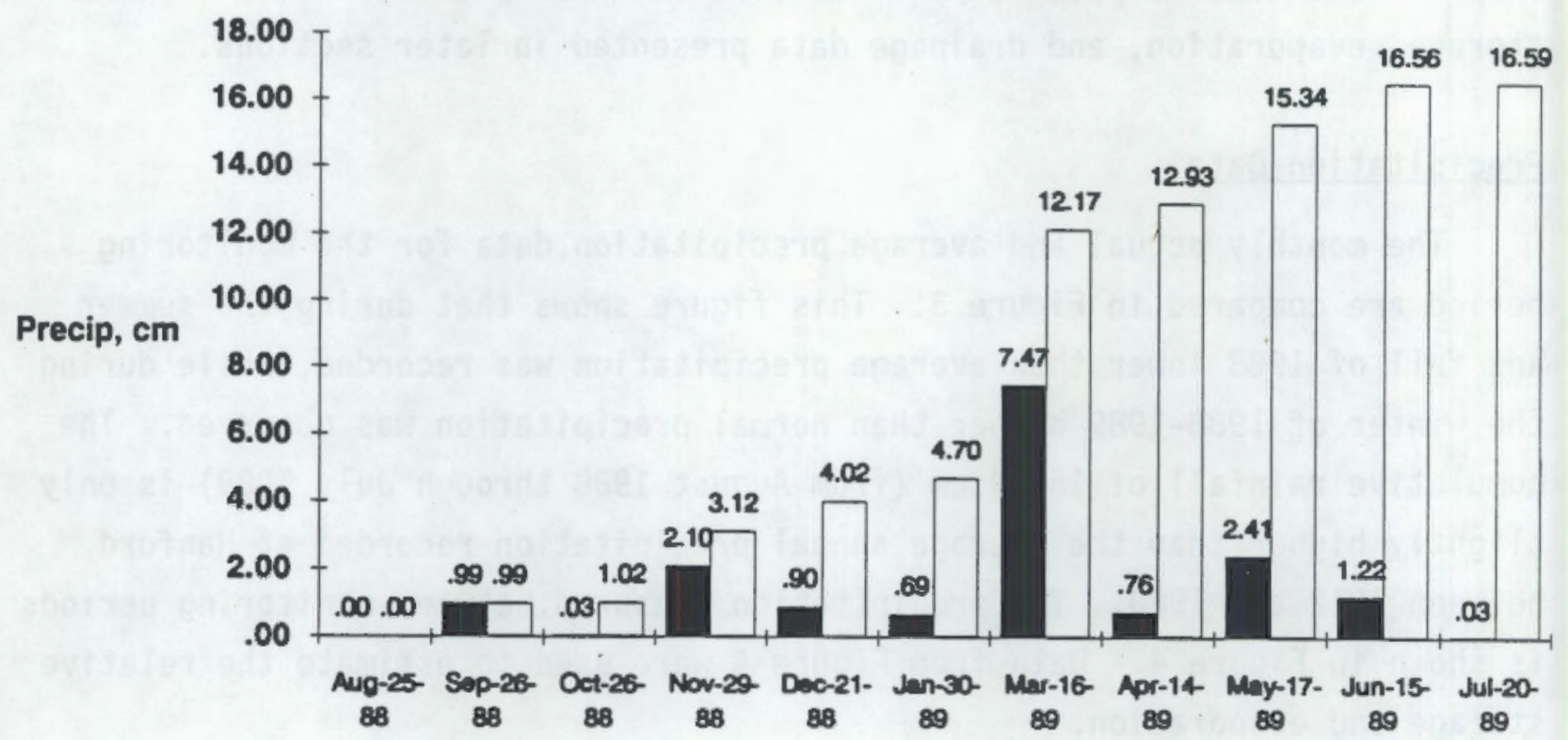

FIGURE 4. Precipitation Measured During Lysimeter Monitoring Intervals

\section{Temperature Data}

Mean daily temperature data are given here to allow interpretation of evaporation and storage data in relation to the long-term average temperatures observed at Hanford. The actual and average daily temperatures are illustrated in Figure 5. During the first year of monitoring, the air temperature averaged $1.3^{\circ} \mathrm{C}$ above normal.

\section{LYSIMETER WATER BALANCE}

The water balance for each lysimeter is determined by weighing the lysimeters with a calibrated crane scale having a resolution of $0.1 \mathrm{~kg}$, then measuring the amount of water that has drained to the bottom of the lysimeter(a). These data are combined with the precipitation data measured at the HMS to obtain the complete water balance for the lysimeters during each measurement interval. During FY 1989, all lysimeters were kept free of

(a) The measured weight changes are converted to an equivalent depth of precipitation by using an average lysimeter inside diameter of $29.5 \mathrm{~cm}$. With this method, $1 \mathrm{~cm}$ of storage is equivalent to $0.685 \mathrm{~kg}$ of water. 


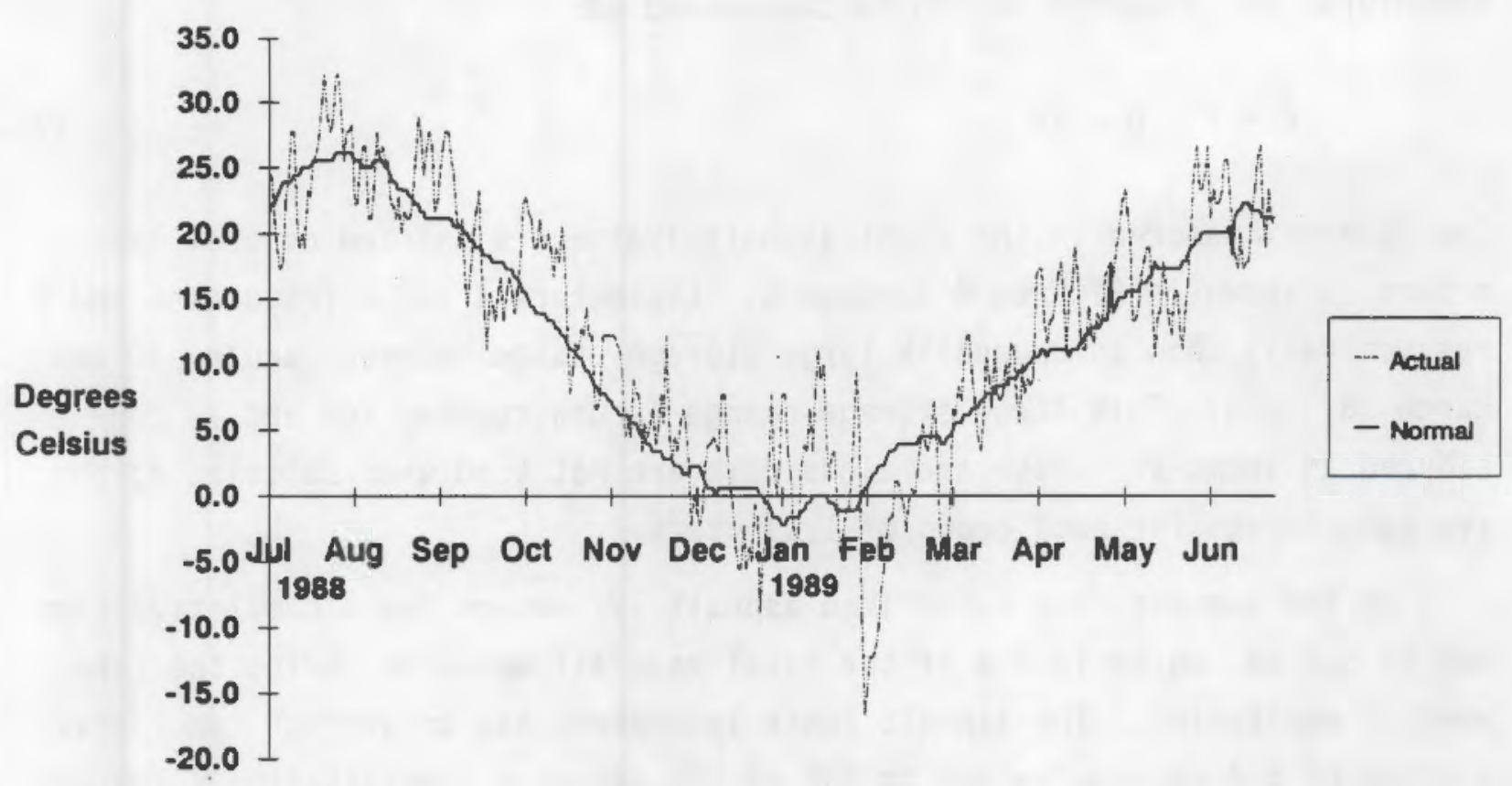

FIGURE 5. Temperature Data Measured at the Hanford Meteorological Station

vegetation except for \#1, \#3, \#5, and \#7. In April 1989, tumbleweed ( $\underline{\text { Salsola }}$ kali) seed was planted on these lysimeters. However, the seed did not germinate. In May, small tumbleweed plants were transplanted on the surface of the four lysimeters. After several weeks, these plants all died except one, which grew very little during the time period. This plant was removed from the surface in June. Since little, if any, transpiration occurred on these lysimeters, we have assumed that all water loss from the surface is evaporation. The water balance equation for the lysimeters is:

$$
P=E+D+\Delta W
$$

where $P=$ precipitation, $\mathrm{cm}$

$E$ = evaporation, $\mathrm{cm}$

$D=$ drainage, $\mathrm{cm}$

$\Delta W=$ change in lysimeter weight from previous measurement interval, $\mathrm{cm}$. 
Therefore, the evaporation can be calculated as:

$$
E=P-D-\Delta W
$$

The storage measured in the eight asphalt lysimeters and two control lysimeters is shown in Figures 6 through 8 . Lysimeters 4 and 6 (Figures 6 and 7, respectively) show an unusually large storage change between January 30 and March 16, 1989: This large storage change is unaccounted for and is considered an anomaly. These anomalous data are not used when calculating the average storage for each group of lysimeters.

On the average, the rubberized asphalt lysimeters had a cumulative storage of $5.2 \mathrm{~cm}$, which is $31 \%$ of the total rainfall measured during the first year of monitoring. The asphalt admix 1ysimeters had an average cumulative storage of $5.4 \mathrm{~cm}$, equivalent to $33 \%$ of the measured precipitation. The two control lysimeters averaged $5.1 \mathrm{~cm}$ of storage, $31 \%$ of the measured precipitation. Also, the control lysimeters drained an additional $4.4 \mathrm{~cm}, 27 \%$ of the

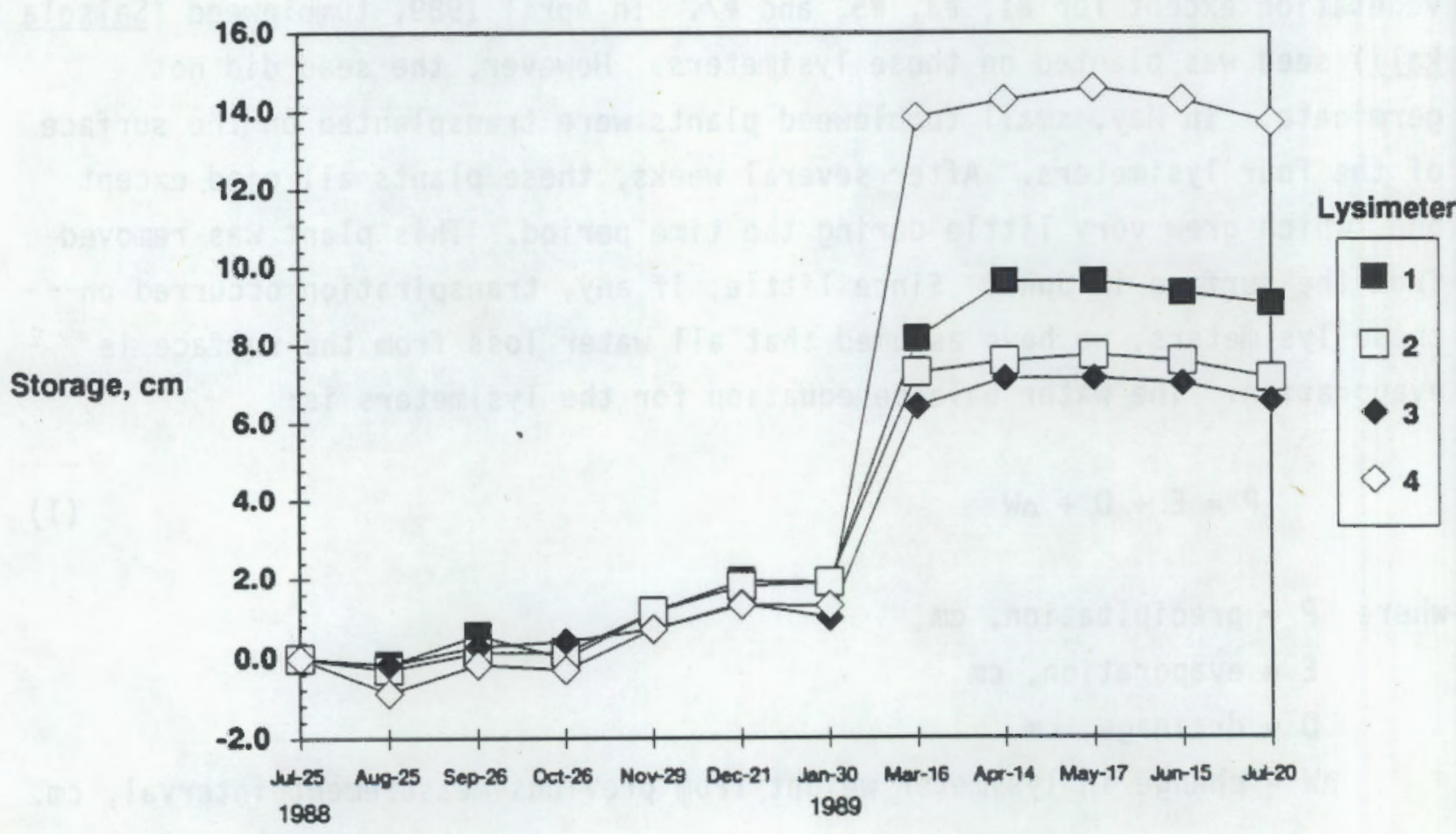

FIGURE 6. Water Storage in the Rubberized Asphalt Lysimeters 


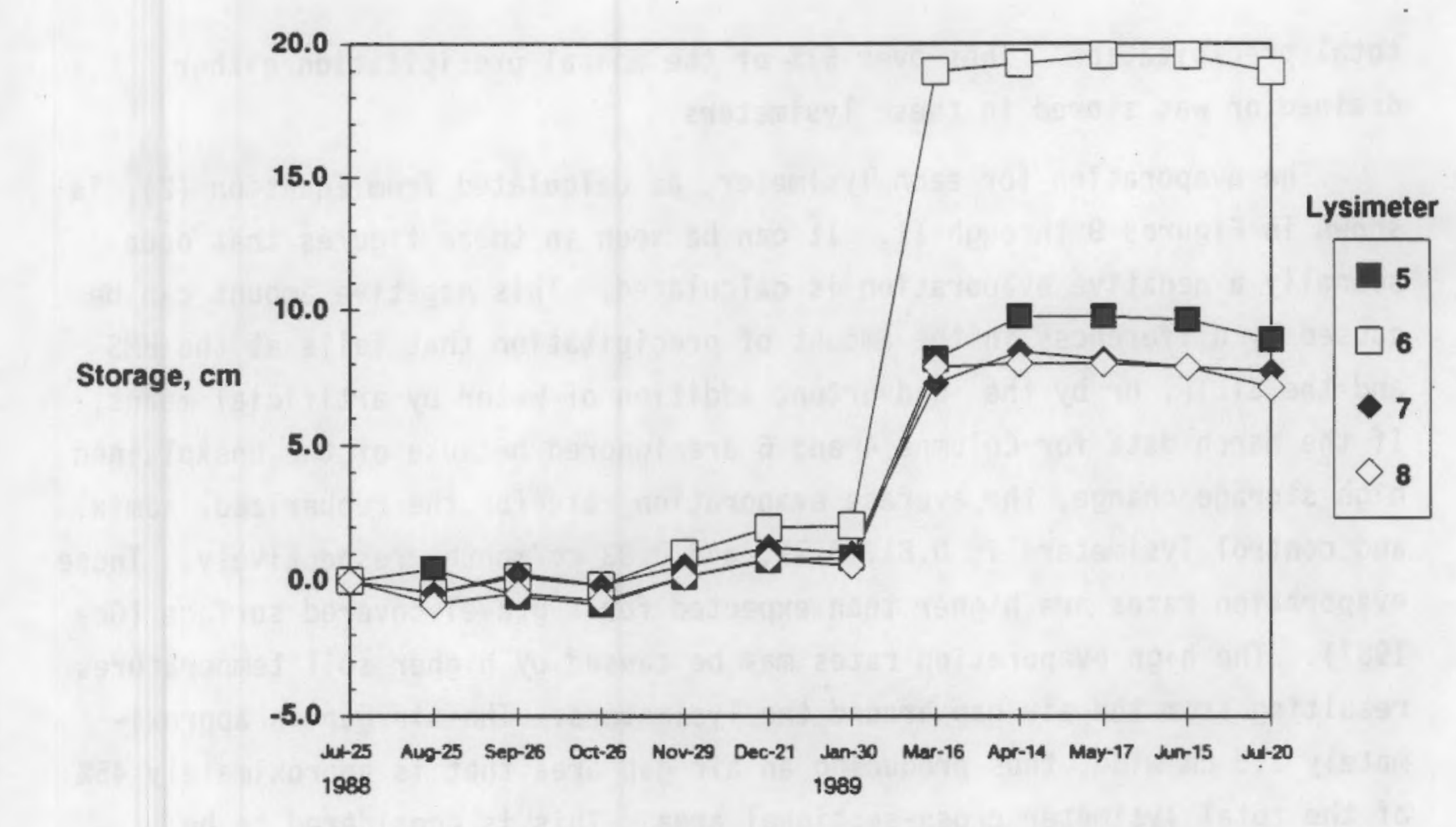

FIGURE 7. Water Storage in the Asphalt Admix Lysimeters

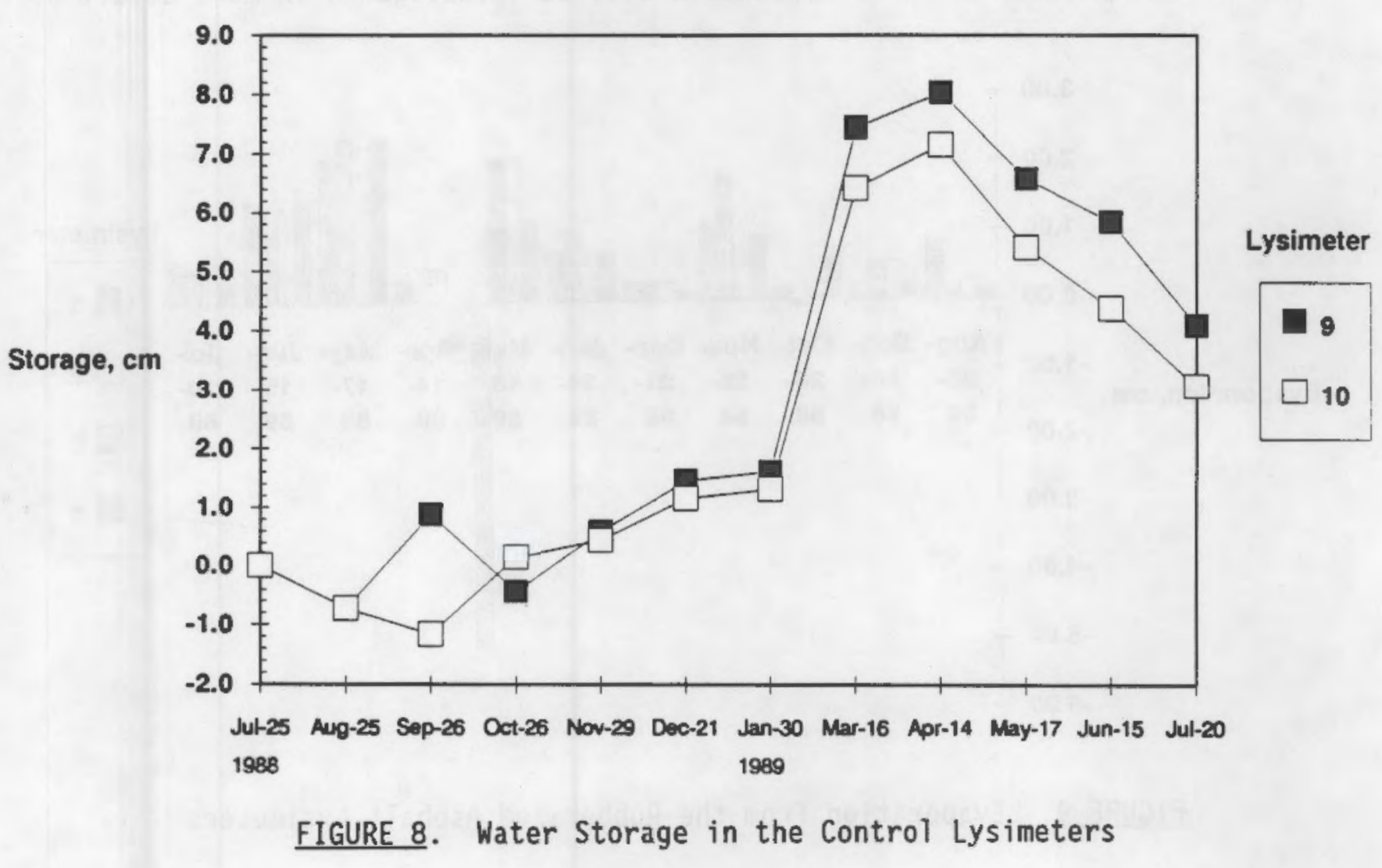


total precipitation. Thus over $51 \%$ of the annual precipitation either drained or was stored in these lysimeters.

The evaporation for each lysimeter, as calculated from Equation (2), is shown in Figures 9 through 11 . It can be seen in these figures that occasionally a negative evaporation is calculated. This negative amount can be caused by differences in the amount of precipitation that falls at the HMS and the STLTF, or by the inadvertent addition of water by artificial means. If the March data for Columns 4 and 6 are ignored because of the unexplained high storage change, the average evaporation rate for the rubberized, admix, and control lysimeters is $0.81,0.77$, and $0.83 \mathrm{~cm} /$ month, respectively. These evaporation rates are higher than expected for a gravel-covered surface (Gee 1987). The high evaporation rates may be caused by higher soil temperatures resulting from the air gap around the lysimeters. The air gap is approximately $2.5 \mathrm{~cm}$ wide, thus producing an air gap area that is approximately $45 \%$ of the total lysimeter cross-sectional area. This is considered to be excessive and should be reduced, possibly by inserting an insulating collar around the lysimeters. This hypothesis will be investigated in more detail

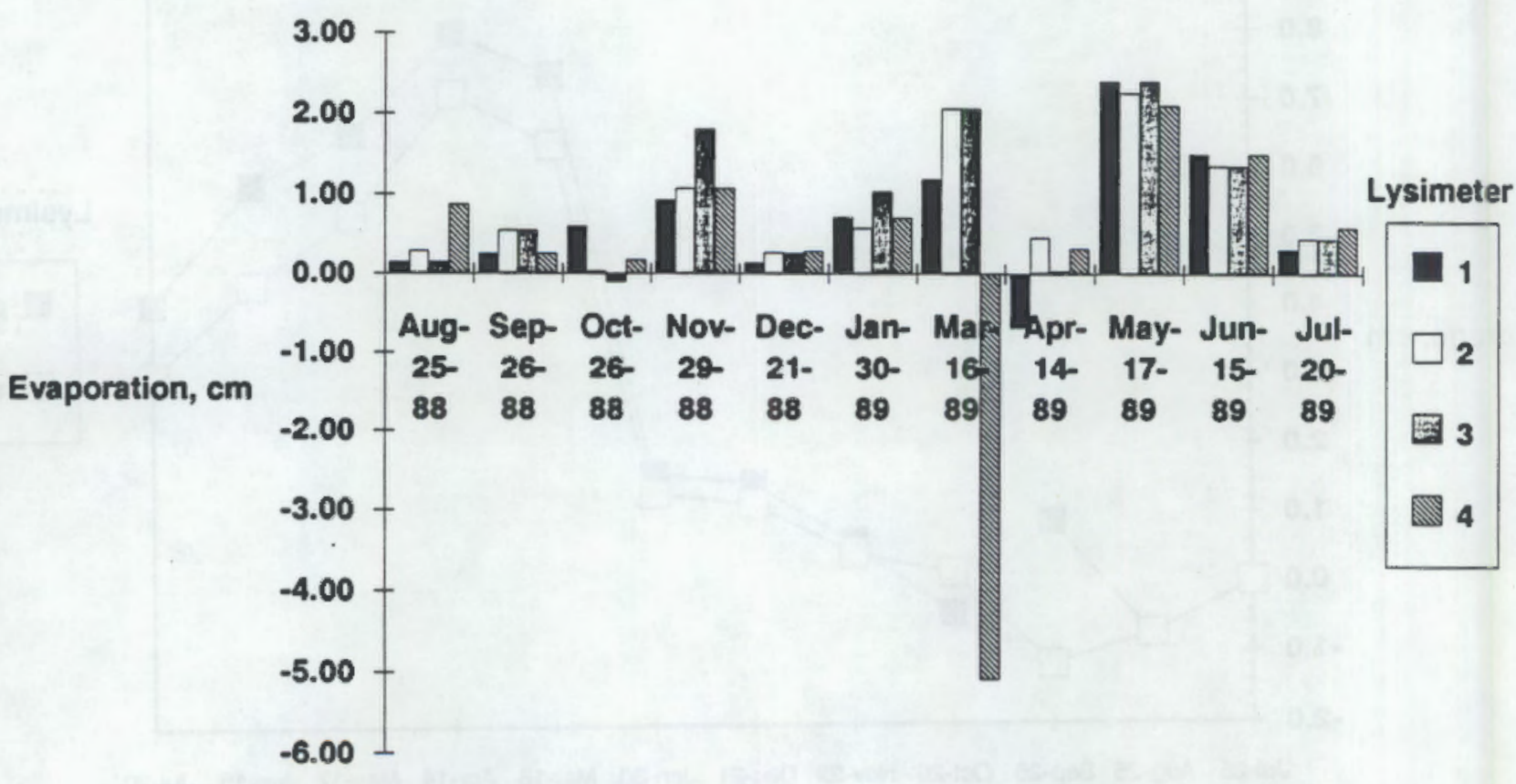

FIGURE 9. Evaporation from the Rubberized Asphalt Lysimeters 


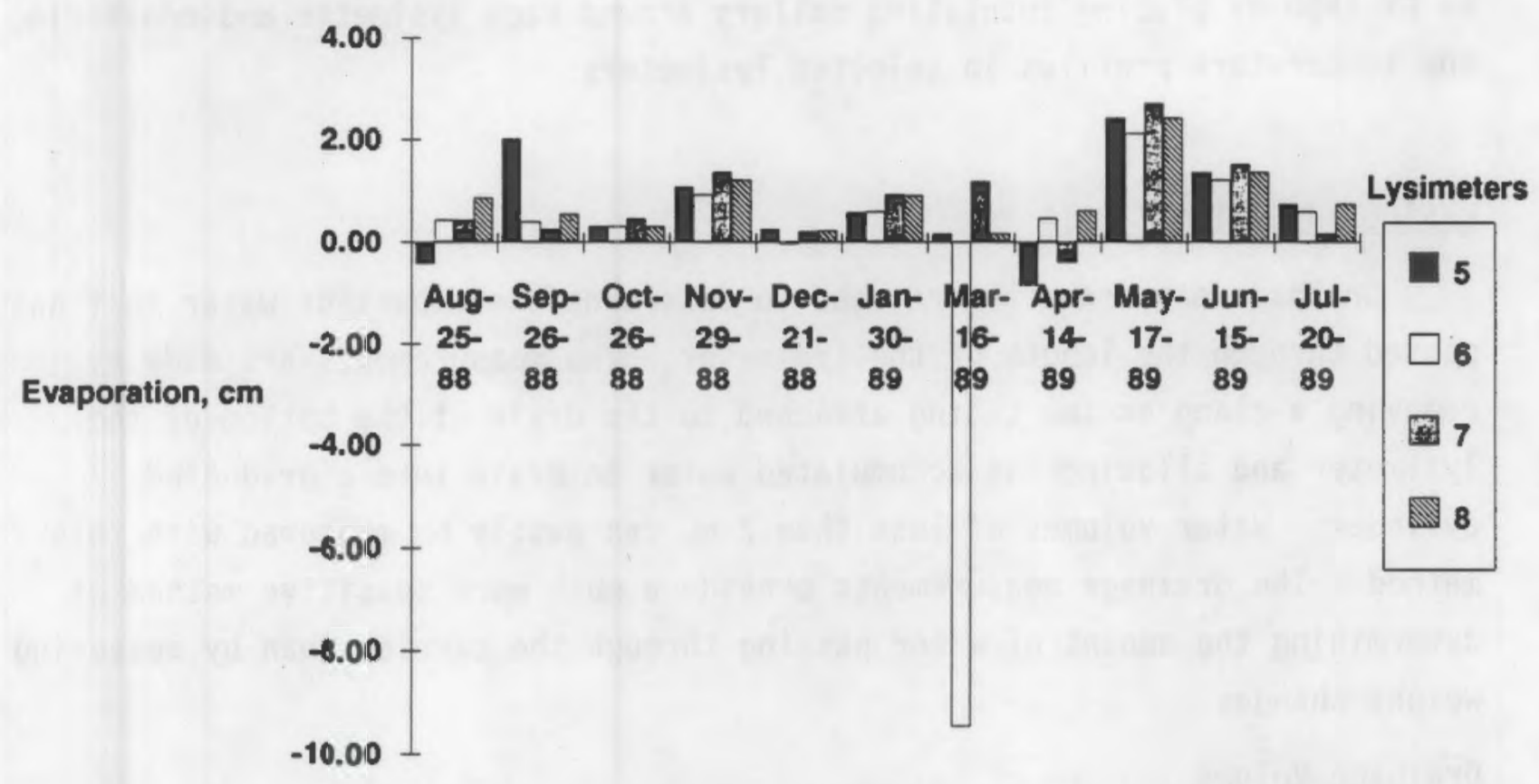

FIGURE 10. Evaporation from the Asphalt Admix Lysimeters

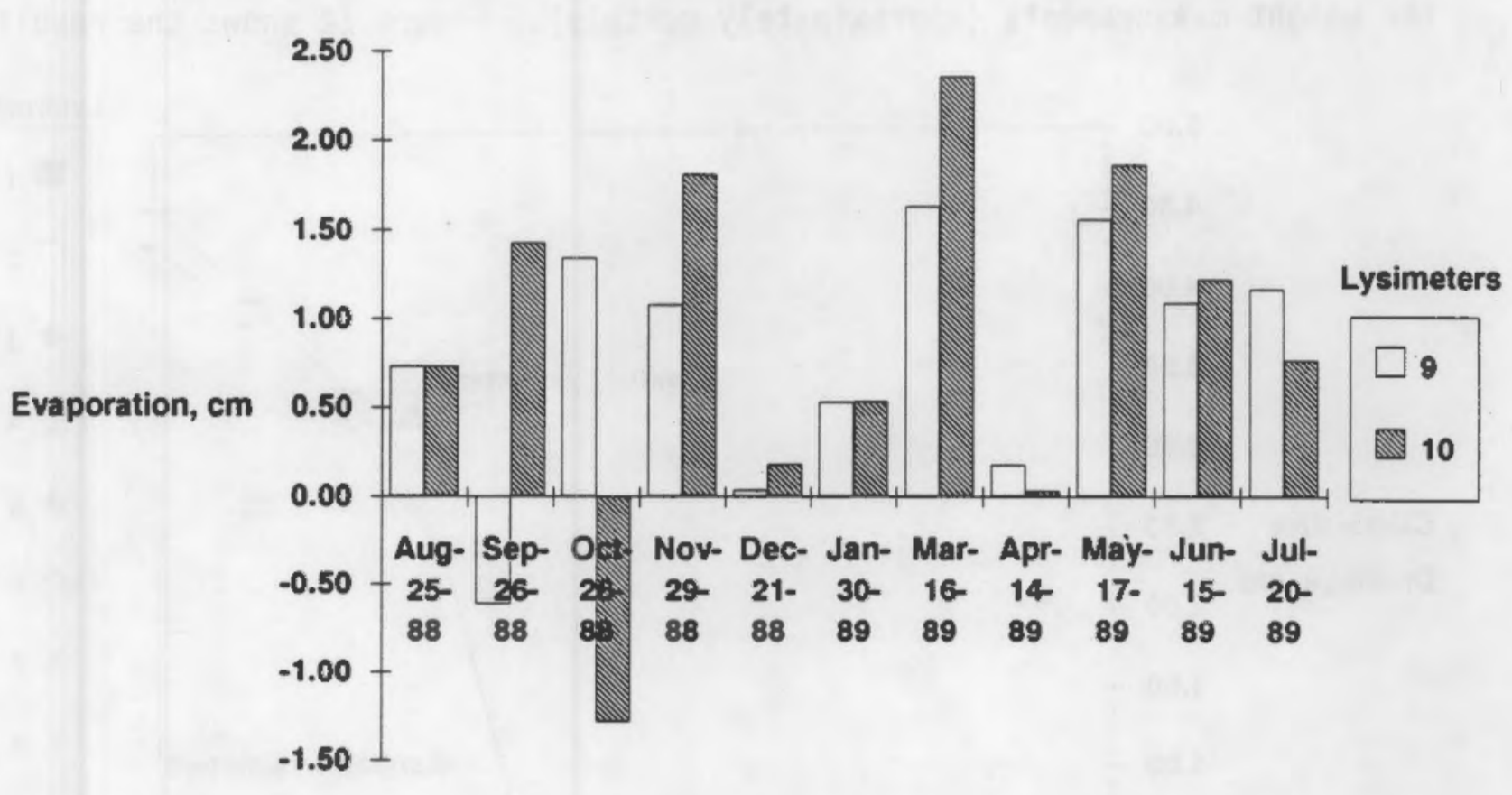

FIGURE 11. Evaporation from the Control Lysimeters 
in FY 1990 by placing insulating collars around each lysimeter and monitoring the temperature profiles in selected lysimeters.

\section{LYSIMETER DRAINAGE DATA}

Drainage measurements are used to determine the amount of water that has passed through the length of the lysimeter. The measurements are made by removing a clamp on the tubing attached to the drain at the bottom of the lysimeter and allowing the accumulated water to drain into a graduated cylinder. Water volumes of less than $2 \mathrm{~mL}$ can easily be measured with this method. The drainage measurements provide a much more sensitive method of determining the amount of water passing through the barrier than by measuring weight changes.

\section{Drainage Volume}

The water accumulated in the bottom of each lysimeter is drained during the weight measurements (approximately monthly). Figure 12 shows the results

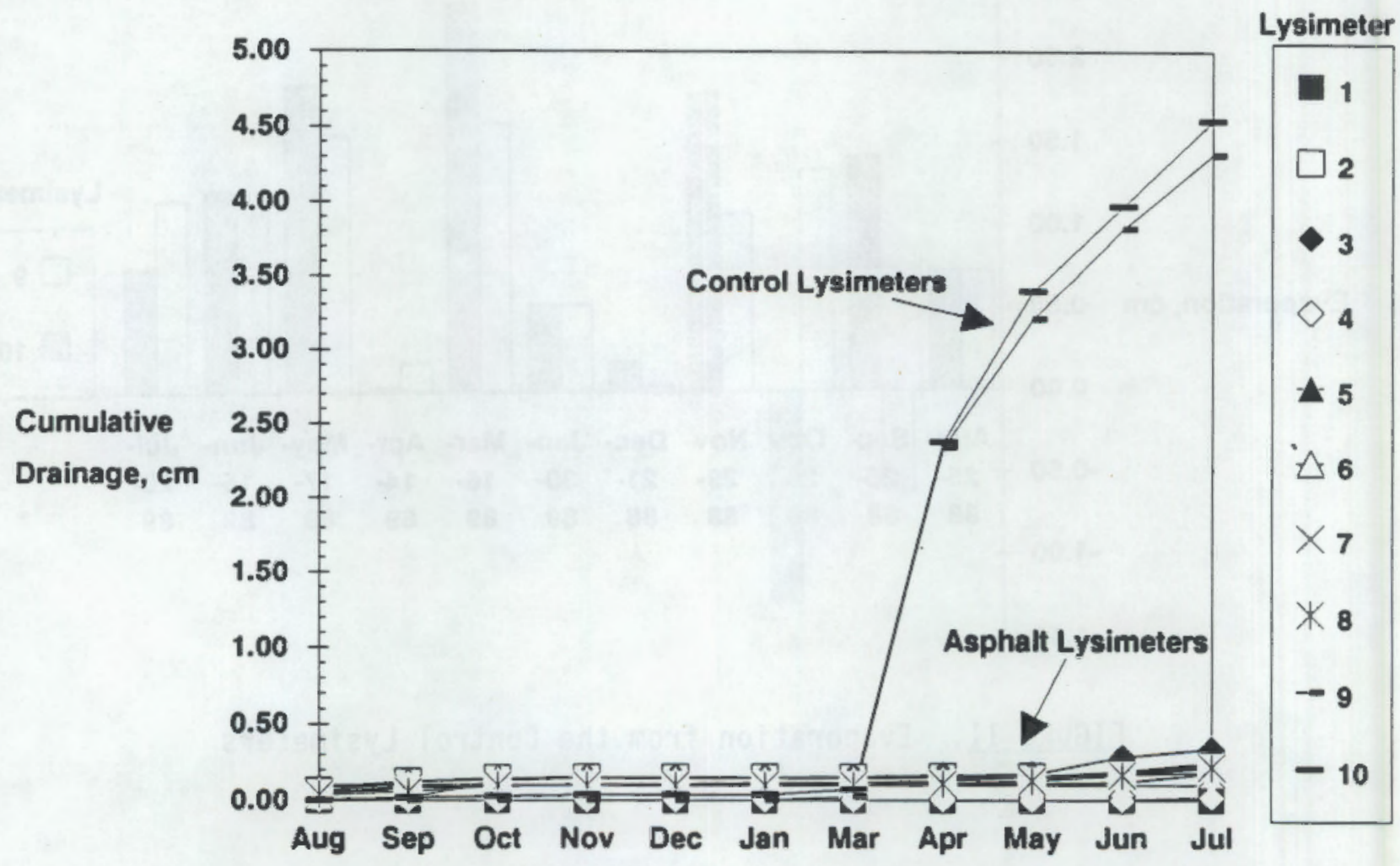

FIGURE 12. Cumulative Drainage from the Alternate Barrier Lysimeters 
of the drainage measurements for the monitoring period. A measurable amount of drainage was collected from all but one of the asphalt lysimeters, but it is still substantially less than that collected from the control lysimeters.

The water found in the asphalt lysimeters is most likely residual moisture from the installation of the barrier materials. The asphalt admix contains large quantities of water in the asphalt emulsion that is expelled when the admixture sets. For the rubberized asphalt columns, the sand placed under the asphalt seal was fairly moist when installed. Initial leak tests of the rubberized asphalt lysimeters revealed pinholes around the perimeter of the column. Part of the water used in the leak tests was transmitted below the seal where it slowly drained out over the year. The pinholes were sealed before the lysimeters were installed in the field.

\section{Drainage Tracer Studies}

The uncertainty of the origin of the water drained from the asphalt lysimeters prompted the initiation of tracer studies. After the lysimeters were monitored in June 1989, a small hole was drilled through the side of each lysimeter above the asphalt seal and in one control lysimeter (\#10), and the lysimeters were injected with $100 \mathrm{~mL}$ of saturated $\mathrm{NaCl}$ solution. The drainage collected in June, before the salt solution was injected, and the drainage collected in July were analyzed for salt content by measuring the conductivity of the sample using a LaMotte Chemical conductivity meter. If the drainage collected from the asphalt lysimeters originated above the barrier, the drain water should show a relatively high conductivity.

The results of the tracer measurements (Figure 13) show that the conductivity of the collected drain water is not significantly different between June and July 1989, except for the control lysimeter. These results indicate that the soil is not sorbing the salts and that the drainage collected from the asphalt lysimeters in July originated below the asphalt seals. The drainage collected in future months will also be monitored for salts. 


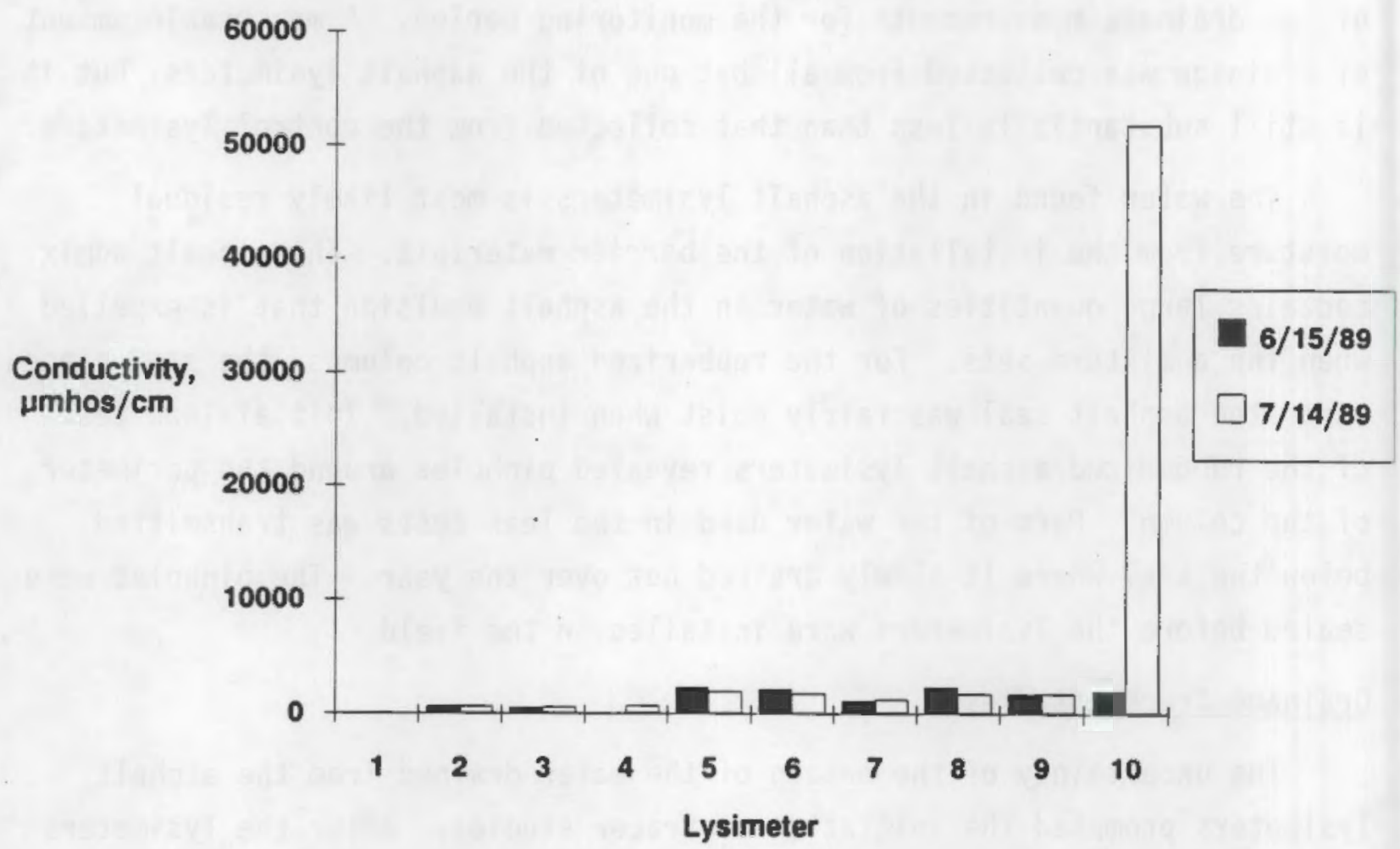

FIGURE 13. Conductivity of Drain Water Collected Before and After Injection of Saturated $\mathrm{NaCl}$ Solution.

\section{CONCLUSIONS}

The results of the first 12 months of monitoring the asphalt and control lysimeters led to the following conclusions:

- No drainage of water through the asphalt barriers was found during the first 12 months of monitoring.

- Additional conductivity analysis of water collected from draining the lysimeters is needed to confirm the preliminary data obtained in July.

- The effect of the air gap around the lysimeters on the evaporation of water should be investigated to determine if it is the cause of higher than expected evaporation rates. 


\section{ASPHALT ADMIX FORMULATION STUDIES}

A number of asphalt emulsion/concrete sand formulation tests were conducted in FY 1989 to improve on the results obtained in FY 1988. During FY 1988 , the only admixture formulation that exceeded the $10^{-9} \mathrm{~cm} / \mathrm{s}$ hydraulic conductivity criterion (Freeman, Gee, and Relyea 1989) was a mixture containing $24 \mathrm{wt} \%$ asphalt. It was expected that the required asphalt content to meet the criterion would be lower ( 18 to $20 \mathrm{wt} \%$ ). The poor results obtained in FY 1988 were 1ikely an artifact of the test procedure, which caused the seals to be subjected to unrealistic stresses to accommodate the permeameter cells. During FY 1989, the test procedure was modified so that the specimens were prepared directly in brass permeameter cells, eliminating the trimming of the specimens required in FY 1988.

Admixture samples were prepared at 18,20 , and $22 \mathrm{wt} \%$ using $+85 \mathrm{mV}$ cationic asphalt emulsion from Akzo Chemie Anerica, and concrete sand obtained from a stockpile near the 200 Area on the Hanford Site. The specimens were compacted using a hydraulic press with a plunger sized to fit snugly inside a $10-\mathrm{cm}$ brass ring. Four small grooves were cut in the perimeter of the plunger to allow air and water to escape during compaction. The samples were compacted at $80 \mathrm{psi}$ and then submitted for hydraulic conductivity tests. The specimen containing $18 \mathrm{wt} \%$ asphalt leaked immediately upon applying 0.5 bar pressure. The 20 and $22 \mathrm{wt} \%$ specimens had a hydraulic conductivity of $3 \times 10^{-7} \mathrm{~cm} / \mathrm{s}$, we 11 above the target of $10^{-9} \mathrm{~cm} / \mathrm{s}$.

Further examination of the specimens showed that they still contained a significant amount of water from the emulsion. The compaction technique used in the laboratory did not allow all of the water to escape and resulted in water-filled voids in the specimens. The retention of water in the admixture is not experienced in the field because water can easily run off of the top and bottom surfaces of the admixture and is squeezed out by the roller during compaction. The conclusion from these tests is that a better laboratory compaction technique, representative of field conditions, is still needed before valid hydraulic conductivity measurements can be made on small specimens. 


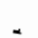

.

. 


\section{REFERENCES}

Adams, M. R., and N. R. Wing. 1986. Protective Barrier and Warning Marker System Development Plan. RHO-RE-PL-35 P, Westinghouse Hanford Company, Richland, Washington.

Freeman, H. D., and G. W. Gee. 1989. Hanford Protective Barriers Program-Aspha1t Barrier Studies - FY 1988. PNL-6874, Pacific Northwest Laboratory, Richland, Washington.

Freeman, H. D., G. W. Gee, and J. F. Relyea. 1989. Field Study Plan for Alternate Barriers. PNL-6840, Pacific Northwest Laboratory, Richland, Washington.

Gee, G. W. 1987. Recharge at the Hanford Site: Status Report. PNL-6403, Pacific Northwest Laboratory, Richland, Washington.

Waugh, J. H., and S. 0. Link. 1987. Barrier Erosion Control Test Plan: Gravel Mulch, Vegetation, and Soil-Water Interactions. WHC-EP-0067, Westinghouse Hanford Company, Richland, Washington. 


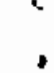




\section{APPENDIX}

LYSIMETER MONITORING DATA 
TABLE A.1. Lysimeter Monitoring Data

Corrected

$1 / 31 / 1989 \mathrm{HDF}$

Asphalt Treatment Small Tube Lysimeter Weights, kg*

\begin{tabular}{|c|c|c|c|c|c|c|c|c|c|c|c|c|c|}
\hline Lysimeter & Treatment & Jul-25-88 & Aug-25-88 & Sep-26-88 & Oct-26-88 & Nov-29-88 & Dec-21-88 & Jan-30-69 & Mar-16-89 & Apr-14-89 & May-17-89 & Jun-15-89 & Jul-20-89 \\
\hline 1 & Rubberized (v) & 224.9 & 224.8 & 225.3 & 224.9 & 225.7 & 226.2 & 226.2 & 230.5 & 231.5 & 231.5 & 231.3 & 231.1 \\
\hline 2 & Rubberized & 225.6 & 225.4 & 225.7 & 225.7 & 226.4 & 226.8 & 226.9 & 230.6 & 230.8 & 230.9 & 230.8 & 230.5 \\
\hline 3 & Rubberized (v) & 226.7 & 226.6 & 226.9 & 227.0 & 227.2 & 227.6 & 227.4 & 231.1 & 231.6 & 231.6 & 231.5 & 231.2 \\
\hline 4 & Rubberized & 224.8 & 224.2 & 224.7 & 224.6 & 225.3 & 225.7 & 225.7 & 234.3 & 234.6 & 234.8 & 234.6 & 234.2 \\
\hline 5 & Admix (v) & 226.7 & 227.0 & 226.3 & 226.1 & 226.8 & 227.2 & 227.3 & 232.3 & 233.4 & 233.4 & 233.3 & 232.8 \\
\hline 6 & Admix & 226.4 & 226.1 & 226.5 & 226.3 & 227.1 & 227.7 & 227.8 & 239.4 & 239.6 & 239.8 & 239.8 & 239.4 \\
\hline 7 & Admix (v) & 229.2 & 228.9 & 229.4 & 229.1 & 229.6 & 230.1 & 229.9 & 234.2 & 235.0 & 234.8 & 234.6 & 234.5 \\
\hline 8 & Admix & 228.6 & 228.0 & 228.3 & 223.1 & 228.7 & 229.2 & 229.0 & 234.0 & 234.1 & 234.1 & 234.0 & 233.5 \\
\hline 9 & Control** & 231.4 & 230.9 & 232.0 & 231.1 & 231.8 & 232.4 & 232.5 & 236.5 & 236.9 & 235.9 & 235.4 & 234.2 \\
\hline 10 & Control** & 231.8 & 231.3 & 231.0 & 231.9 & 232.1 & 232.6 & 232.7 & 236.2 & 236.7 & 235.5 & 234.8 & 233.9 \\
\hline
\end{tabular}

- Weights include aluminum collar and shackles

December Weights $1.08 \%$ Low due to bad scale calibration. Values above are corrected

" * weight before draining accumulated water

(v) Lysimeters scheduled to have sagebrush planted in the Fall of 1989

Change in Storage, $\mathrm{kg}$

\begin{tabular}{|c|c|c|c|c|c|c|c|c|c|c|c|c|c|}
\hline Lysimeter & Treatment & Jul-25-88 & Aug-25-88 & Sep-26-88 & Oct-26-88 & Nov-29-88 & Dec-21-88 & Jan-30-89 & Mar-16-89 & Apr-14-89 & May-17-89 & Jun-15-89 & Jul-20-89 \\
\hline 1 & Rubberized & & -0.1 & 0.5 & \begin{tabular}{|l|}
-0.4 \\
\end{tabular} & 0.8 & 0.5 & 0.0 & 4.3 & 1.0 & 0.0 & -0.2 & -0.2 \\
\hline 2 & Rubberized & & -0.2 & 0.3 & 0.0 & 0.7 & 0.4 & 0.1 & 3.7 & 0.2 & 0.1 & -0.1 & -0.3 \\
\hline 3 & Aubberized & & -0.1 & 0.3 & 0.0 & 0.3 & 0.4 & -0.2 & 3.7 & 0.5 & 0.0 & -0.1 & -0.3 \\
\hline 4 & Rubberized & & .0 .6 & 0.5 & -0.1 & 0.7 & 0.4 & 0.0 & 8.6 & 0.3 & 0.2 & -0.2 & -0.4 \\
\hline 5 & Admix & & & -0.7 & -0.2 & 0.7 & 0.4 & 0.1 & 5.0 & 1.1 & 0.0 & -0.1 & -0.5 \\
\hline 6 & Admix & & -0.4 & 0.4 & -0.2 & 0.8 & 0.6 & 0.1 & 11.6 & 0.2 & 0.2 & 0.0 & -0.4 \\
\hline 7 & Admix & & -0.3 & 0.5 & -0.3 & 0.5 & 0.5 & -0.2 & 4.3 & 0.8 & -0.2 & -0.2 & -0.1 \\
\hline 8 & Admix & & -0.6 & 0.3 & -0.2 & 0.6 & 0.5 & -0.2 & 5.0 & 0.1 & 0.0 & -0.1 & -0.5 \\
\hline 9 & Control & & -0.5 & 1.1 & -0.9 & 0.7 & 0.6 & 0.1 & 4.0 & -1.2 & 0.0 & -0.3 & -1.1 \\
\hline \multirow[t]{11}{*}{10} & Control & & -0.5 & -0.3 & 0.9 & 0.2 & 0.5 & 0.1 & 3.5 & -1.1 & -0.3 & -0.4 & -0.9 \\
\hline & & & & & & & & & & & & & \\
\hline & Rainfall, cm & & 0.00 & 0.99 & 0.03 & 2.10 & 0.90 & 0.69 & 7.47 & 0.76 & 2.41 & 1.22 & 0.03 \\
\hline & Cumulative $F$ & fall, $\mathrm{cm}$ & 0 & 0.99 & 1.02 & 3.12 & 4.02 & 4.70 & 12.17 & 12.93 & 15.34 & 16.56 & 16.59 \\
\hline & $100 \%$ Storag & & 0 & 0.7 & 0.0 & 1.4 & 0.6 & 0.5 & 5.1 & 0.5 & 1.7 & 0.8 & 0.0 \\
\hline & Average Stor & $\%$ & 0 & 43 & 0 & 42 & 79 & -3 & 105 & 38 & 0 & -21 & -2786 \\
\hline & Average Wei & Change, & -0.4 & 0.3 & -0.1 & 0.6 & 0.5 & 0.0 & 5.4 & 0.2 & 0.0 & -0.2 & -0.5 \\
\hline & Cumulative & ght Chang & -0.3 & 0.0 & -0.1 & 0.5 & 1.0 & 0.9 & 6.3 & 6.5 & 6.5 & 6.3 & 5.8 \\
\hline & Avg ET, kg & & 0.4 & 0.4 & 0.1 & 0.8 & 0.1 & 0.5 & -0.3 & 0.3 & 1.7 & 1.0 & 0.5 \\
\hline & Avg ET, cm & & 0.1 & 0.5 & 0.2 & 1.2 & 0.2 & 0.7 & -0.4 & 0.5 & 2.3 & 1.4 & 0.7 \\
\hline & Cumulative $\mathrm{E}$ & & 0.0 & 0.5 & 0.7 & 1.9 & 2.1 & 2.8 & 2.4 & 2.9 & 5.2 & 6.6 & 7.3 \\
\hline
\end{tabular}




\section{TABLE A.1. Lysimeter Monitoring Data (contd)}

Drainage from Asphat Small Tube Lysimeters, $\mathrm{ml}$

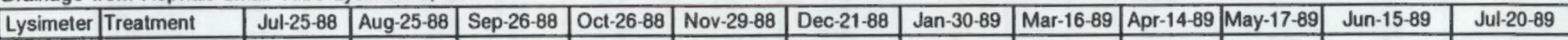

\begin{tabular}{|c|c|c|c|c|c|c|c|c|c|c|c|c|c|}
\hline & & & & & & & & & & & & & \\
\hline 1 & Rubberized & & 0 & 0 & 0 . & 0 & 0 & 0 & 0 & 0 & 0 & 0 & 0 \\
\hline 2 & Rubberized & & 40 & 40 & 16 & 5 & 0 & 0 & 0 & 2 & 0 & 16 & 41 \\
\hline 3 & Rubberized & & 2 & 7 & 83 & 11 & 66 & 1 & 4 & 4 & 4 & 13 & 37 \\
\hline 4 & Rubberized & & 0 & 0 & 0 & 0 & 0 & 0 & 0 & 0 & 0 & 0 & 14 \\
\hline 5 & Admix & & 30 & 35 & 0 & 5 & 0 & 9 & 0 & 8 & 20 & 24 & 38 \\
\hline 6 & Admix & & 55 & 29 & 16 & 5 & 0 & 0 & 0 & 0 & 0 & 7 & 16 \\
\hline 7 & Admix & & 20 & 35 & 13 & 0 & 0 & 1 & 0 & 0 & 4 & 7 & 40 \\
\hline 8 & Admix & & 25 & 13 & 30 & 0 & 0 & 1 & 0 & 4 & 14 & 25 & 37 \\
\hline 8 & Control & & 0 & 0 & 0 & 0 & 0 & 1 & 15 & 1588 & 592 & 420 & 340 \\
\hline 10 & Control & & 0 & 13 & 6 & 5 & 0 & 0 & 25 & 1580 & 697 & 395 & 392 \\
\hline Cumulativ & e Drainage, $\mathrm{ml}$ & & Aug-25-88 & Sep-26-88 & Oct-26-88 & Nov-29-88 & Dec-21-68 & Jan-30-89 & Mar-16-89 & Apr-14-89 & May-17-89 & Jun-15-89 & Jul-20-89 \\
\hline 1 & Rubberized & & 0 & 0 & 0 & 0 & 0 & 0 & 0 & 0 & 0 & 0 & 0 \\
\hline 2 & Aubberized & & 40 & 80 & 96 & 101 & 101 & 101 & 101 & 103 & 103 & 119 & 160 \\
\hline 3 & Rubberized & & 2 & 9 & 92 & 103 & 169 & 170 & 174 & 178 & 182 & 195 & 232 \\
\hline 4 & Rubberized & & 0 & 0 & 0 & 0 & 0 & 0 & 0 & 0 & 0 & 0 & 14 \\
\hline 5 & Admix & & 30 & 65 & 65 & 70 & 70 & 79 & 79 & 87 & 107 & 131 & 169 \\
\hline 6 & Admix & & 55 & 84 & 100 & 105 & 105 & 105 & 105 & 105 & 105 & 112 & 128 \\
\hline 7 & Admix & & 20 & 55 & 68 & 68 & 68 & 69 & 69 & 69 & 73 & 80 & 120 \\
\hline 8 & Admix & $\cdot$ & 25 & 38 & 68 & 68 & 68 & 69 & 69 & 73 & 87 & 112 & 149 \\
\hline 9 & Control & & 0 & 0 & 0 & 0 & 0 & 1 & 16 & 1604 & 2196 & 2616 & 2956 \\
\hline 10 & Control & & 0 & 13 & 19 & 24 & 24 & 24 & 49 & 1629 & 2326 & 2721 & 3113 \\
\hline
\end{tabular}

Evaporation,cm

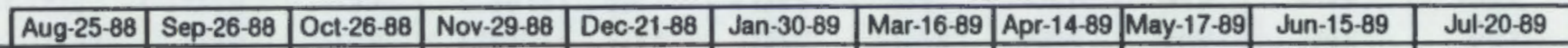

\begin{tabular}{|c|c|c|c|c|c|c|c|c|c|c|c|c|}
\hline 1 & Rubberized & 0.15 & 0.26 & 0.61 & 0.93 & 0.13 & 0.72 & 1.19 & -0.70 & 2.41 & 1.51 & 0.32 \\
\hline 2 & Rubberized & 0.35 & 0.55 & -0.01 & 1.06 & 0.26 & 0.59 & 2.07 & 0.47 & 2.26 & 1.39 & 0.50 \\
\hline 3 & Rubberized & 0.15 & 0.56 & -0.01 & 1.70 & 0.34 & 0.94 & 2.07 & 0.03 & 2.41 & 1.38 & 0.50 \\
\hline 4 & Rubberized & 0.88 & 0.26 & 0.17 & 1.08 & 0.29 & 0.72 & -5.09 & 0.32 & 2.12 & 1.51 & 0.63 \\
\hline 5 & Admix & VALUE! & 2.02 & 0.27 & 1.09 & 0.28 & 0.61 & 0.16 & -0.63 & 2.43 & 1.37 & 0.78 \\
\hline 6 & Admix & 0.52 & 0.37 & 0.30 & 0.92 & -0.04 & 0.60 & -9.47 & 0.47 & 2.12 & 1.23 & 0.62 \\
\hline 7 & Admix & 0.47 & 0.28 & 0.43 & 1.35 & 0.22 & 0.93 & 1.19 & -0.41 & 2.71 & 1.52 & 0.22 \\
\hline 8 & Admix & 0.91 & 0.53 & 0.34 & 1.18 & 0.23 & 0.92 & 0.17 & 0.62 & 2.43 & 1.38 & 0.77 \\
\hline 9 & Control & 0.73 & -0.62 & 1.34 & 1.08 & 0.04 & 0.53 & 1.65 & 2.47 & 2.42 & 1.70 & 1.66 \\
\hline 10 & Control & 0.73 & 1.45 & -1.30 & 1.81 & 0.17 & 0.53 & 2.39 & 2.30 & 2.88 & 1.80 & 1.33 \\
\hline
\end{tabular}


PNL -7153

UC -510

\section{DISTRIBUTION}

No. of

Copies

OFFSITE

2 DOE/Office of Scientific and Technica] Information

\section{ONSITE}

7 DOE Richland Operations Office
G. J. Bracken
J. J. Broderick
R. D. Freeburg
R. E. Gerton
R. D. Izatt
S. M. Prestwich
G. W. Rosenwald

23 Westinghouse Hanford Company
M. R. Adams
L. C. Brown
J. W. Cammann
R. A. Carlson
H. F. Daugherty
W. F. Heine
J. M. Henderson
G. W. Jackson
C. J. Kemp
K. N. Jordan
D. S. Landeen
R. E. Lerch
H. E. McGuire
K. W. Dwens
K. L. Petersen
J. F. Relyea
M. R. Sackschewsky

No. of

Copies
D. A. Turner
S. A. Weigman
N. R. Wing
D. D. Wodrich
R. Wojtasek
D. E. Wood

41 Pacific Northwest Laboratory

L. L. Cadwell

M. D. Campbe11

D. A. Cataldo

J. W. Falco

M. J. Fayer

M. G. Foley

H. D. Freeman (10)

G. W. Gee (2)

T. L. Jones

C. T. Kincaid

R. R. Kirkham

D. C. Klopfer

G. V. Last

M. W. Ligotke

S. 0. Link

W. H. Rickard

M. L. Rockhold

L. E. Rogers

R. L. Skaggs

J. A. Stottlemyre

C. P. Streile

M. E. Thiede

J. M. Thomas

W. J. Waugh

R. E. Wildung

Publishing Coordination

Technica] Report Files (5) 
